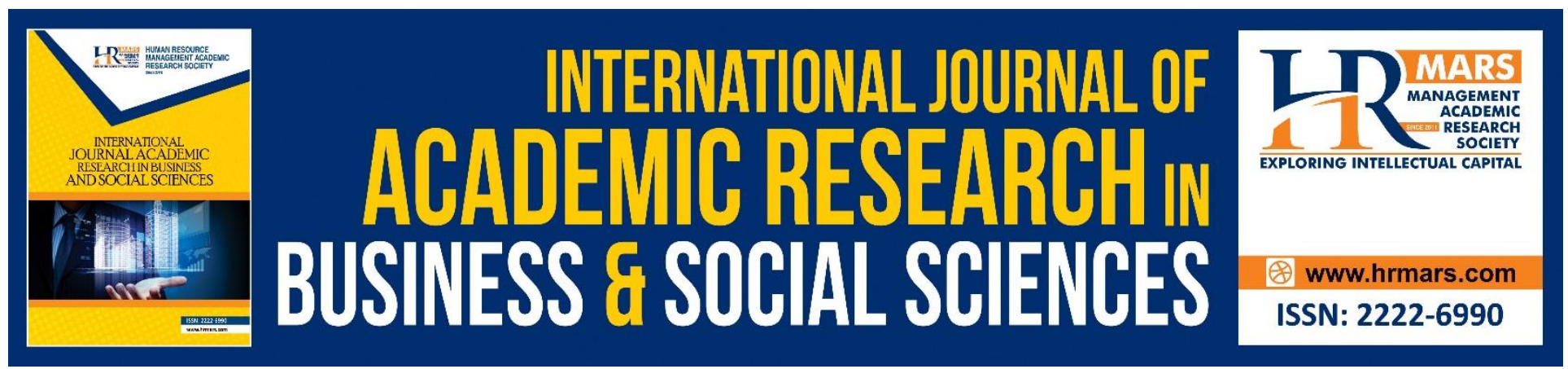

\title{
Reliability and Validity of the ACREDA Religious Self- Regulation Questionnaire (ASRQ-R)
}

Mohd Khairul Anuar Bin Rahimi, Mohamad Salleh bin Abdul Ghani, Norizatul Masturah Binti Mohd Zaki, Mohamad Isa Bin Amat, Haslee Sharil Lim Abdullah and Muhammad Khairi Bin Mahyuddin

To Link this Article: http://dx.doi.org/10.6007/IJARBSS/v8-i11/4945 DOI: $10.6007 /$ IJARBSS/v8-i11/4945

Received: 30 Sept 2018, Revised: 27 Oct 2018, Accepted: 16 Nov 2018

Published Online: 28 Nov 2018

In-Text Citation: (Rahimi et al., 2018)

To Cite this Article: Rahimi, M. K. A. Bin, Ghani, M. S. bin A., Zaki, N. M. B. M., Amat, M. I. Bin, Haslee Sharil Lim Abdullah, \& Mahyuddin, M. K. Bin. (2018). Reliability and Validity of the ACREDA Religious Self-Regulation Questionnaire (ASRQ-R). International Journal of Academic Research in Business and Social Sciences, 8(11), 676-685.

Copyright: (C) 2018 The Author(s)

Published by Human Resource Management Academic Research Society (www.hrmars.com) This article is published under the Creative Commons Attribution (CC BY 4.0) license. Anyone may reproduce, distribute, translate and create derivative works of this article (for both commercial and non-commercial purposes), subject to full attribution to the original publication and authors. The full terms of this license may be seen at: http://creativecommons.org/licences/by/4.0/legalcode

Vol. 8, No. 11, 2018, Pg. 676 - 685 


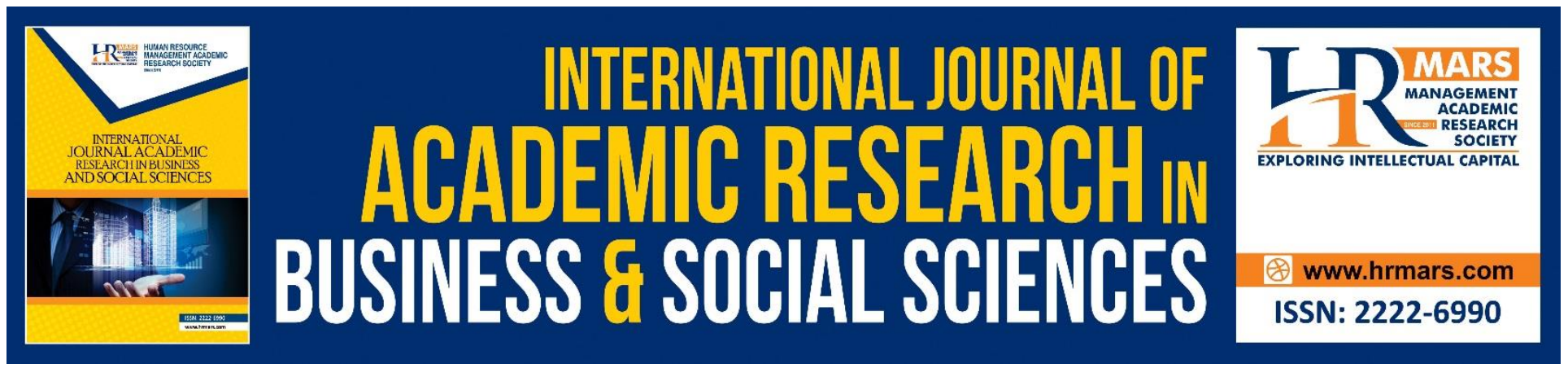

\title{
Reliability and Validity of the ACREDA Religious Self-Regulation Questionnaire (ASRQ-R)
}

\author{
${ }^{1}$ Mohd Khairul Anuar Bin Rahimi, ${ }^{2}$ Mohamad Salleh bin Abdul \\ Ghani, ${ }^{2}$ Norizatul Masturah Binti Mohd Zaki, ${ }^{2}$ Mohamad Isa Bin \\ Amat, ${ }^{1}$ Haslee Sharil Lim Abdullah and ${ }^{1}$ Muhammad Khairi Bin \\ Mahyuddin \\ ${ }^{1}$ Faculty of Leadership and Management,
} Islamic Science Unversity of Malaysia, Bandar Baru Nilai, 71800, Nilai Negeri Sembilan, Malaysia

${ }^{2}$ Asian Centre of Research on Drug Abuse (ACREDA), Islamic Science Unversity of Malaysia, Bandar Baru Nilai, 71800, Nilai Negeri Sembilan, Malaysia

Abstract: Drug addiction remains a problem even after the establishment of different rehabilitation centers around Malaysia. Religiosity has been suggested as the way forward in combating drug addiction in a conservative Malaysian population. However, religiosity behavior has not been conclusively researched in Malaysia. Thus, this study examines the validity and reliability of the ACREDA Religious Self-Regulation Questionnaire (ASRQ- $R$ ) among recovering addicts in Malaysia. This instrument is adapted from the original 48-item ASRQ-R inventory by Ryan, Rigby, and King (1993) into a shorter, 12-item instrument. The instrument aimed to examine the motivation as to why a person engages in religious behavior and will. The instrument was back translated by language experts to maintain its authenticity, and face validity were done by counselling experts to examine its content. 86 residents at a drug rehabilitation centre in Sepang were chosen to gauge the reliability scores of the instrument. Analysis of the reliability indicated a Cronbach's Alpha score of 0.895 , indicating high reliability. This provides evidence that the instrument is acceptable to be used in a Malaysian context, specifically the Malay Muslim population.

Keywords: Reliability, Validity, ACREDA, ASRQ-R, Back Translation 


\section{INTRODUCTION}

Drug rehabilitation remains a focus for Malaysia in the $21^{\text {st }}$ century due to the importance of ensuring the well-being of its citizens. Various steps are already underway by the government to ensure that it is handled accordingly. As reporting by National Anti-Drug Agency of Malaysia (NADA, 2015), drug addiction cases has reached a worrying level with 26,668 cases. Among the number, about 6,739 were relapsed patients. As has been mentioned in Halpert and Hill (2011), drug addiction occurs due to the uncontrolled state of addicts which has manifested into their behavior and emotions. It indirectly encourages the drug addict to depend on the use of illegal substances as a means of coping for their real-life problems (Allahverdipour, Maclntyre, Hidarnia, Shafii, Kazemnegad, Galeiha \& Emami, 2007). Emphasizing on religious practice has been suggested as one of the most effective methods in drug rehabilitation.

Religiosity is defined as the complex dimension of a person's behaviour and religious will, regardless of the content of his or her beliefs (Amey, Albrecht, \& Miller, 1996). Behavior is one of the most crucial points that should be emphasized on to curb drug addiction issues. A research by Richard, Bell and Carlon (2000) found a positive correlation between the application of religiosity practices and the frequency of attending church. This has led to a reduction on their use of alcohol and cocaine (Richard et al., 2000). This provides evidence of the effects of religion on eliminating negative behaviors. Moreover, the finding by Amoateng and Bahr (1989) indicate that religiosity has been attributed to positive results as a preventative step in reducing drug addiction.

Religion can also change behavior-influencing values and act as the external control factor. For example, a study conducted by Kutter and McDermott (1997) found three dimension of religiosity concept: (a) prescriptiveness, (b) involvement in church (or synagogue or mosque) activities, and (c) the importance placed on those activities. Other researchers look at religion from a different perspective as they would separate private and public religious behaviour. Private religiosity behaviour is defined as a person who prefer to do perform their religious practices privately, such as praying individually. Meanwhile, public religiosity behaviour is defined as people who tend to perform it within a group of people such as attending a public religious speech, attending religious services and perform congregational prayer (Bahr, Maughan, Marcos, \& Li, 1998; Hill, 2000). Thus, the concept of religiosity had become a part of important point of view in one's self.

However, there is still a shortage of any good instrument that could be used to measure a drug addict's religious behavior, especially in a Malaysian context. Having scoured through the literature, it was found that religiosity questionnaire specifically for drug addicts has not been validated for use in a Malaysian context. So, a suitable questionnaire needs to be found so that it could be used in a study measuring religious behavior. After looking at different questionnaires, it was agreed by all authors that an instrument originally developed by Ryan, Rigby, and King (1993) would be appropriate for use in the study. In short, this paper aims at growing the literature by presenting the validity and reliability of the ACREDA Religious Self-Regulation Questionnaire (ASRQ-R) instrument as a valid construct to measure religious behavior. This instrument was originally developed by Ryan, Rigby, and King (1993), however the instrument 
has been adapted to fit with the Malay Muslim population in Malaysia. Besides, it is also able to enrich the literature for the recovery of drug addicts from a religious perspective. In relation to previous findings, present study aimed to measure the validation of Islamic application among the drug inmates in recovery process to validate the reliability and validity scores.

\section{MATERIALS AND METHOD}

The authors conducted a quantitative study to examine the validity and reliability of an instrument related to religiosity behavior. This study involved 86 male Muslim in recovery process who were aged between 21 to 50 years old. All respondents were selected from the Cure \& Care Vocational Centre in Sepang, Malaysia. The authors used a translated version of the religious self-regulating questionnaire in the Malay language for all respondents. The ACREDA $S R Q-Q$ is a short questionnaire which can be answered by the respondent within 5 minutes. The respondents were informed that there is no right or wrong answer to ensure that they answer it truthfully.

\begin{tabular}{crrrrrc}
1 & 2 & 3 & 4 & 5 & 6 & 7 \\
Not at all true & & \multicolumn{3}{c}{ Somewhat true } & & Very true
\end{tabular}

A. One reason I think it's important to actively share my faith with others is:

1. Because Allah is important to me and l'd like other people to know about Him too.

2. Because I would feel bad about myself if I didn't.

3. Because I want other Muslims to approve of me.

B. When I turn to Allah, I most often do it because:

4. I enjoy spending time with Him.

5. I would feel guilty if I didn't.

6. I find it is satisfying to me.

C. A reason I think praying is important is:

7. Because if I don't, Allah will disapprove of me.

8. Because I enjoy praying.

9. Because I find prayer satisfying.

D. An important reason why I attend Masjid is:

10. Because one is supposed to go to Masjid.

11. By going to Masjid, I learn new things.

12. Because others would disapprove of me if I didn't.

Table 1.0: Religious Self-regulating Questionnaire (ASRQ-R)

Table 1.0 represents the adapted version of the ACREDA SRQ-R to fit into the Islamic worldview. It includes 12 items to be answered by the respondents that were related to the 
Islamic religious aspect measured using the 7-point Likert scale. The values from 1 to 7 represents a continuum from "not at all true", "somewhat true" to "very true".

The instrument was originally developed by Ryan, Rigby, and King (1993) from the Department of Psychology, University of Rochester, New York. The instrument mainly focuses on the reason of why a person would be involved in religious behaviour. When it was first used, the instrument would only focus on Christian practices, but it can be modified to suit different religions. Originally, 48 items were used, however the current 12 items instrument were chosen as it is far more economical. Hence, two subscales represent the meaningful reason on why a person would be involved in religious behaviour, which are the introjection regulation and identified regulation. The scoring process involved calculating the scores for Introjected Regulation and Identified Regulation by averaging the items within those subscales. For Identified Regulation, item 1, 4, 6, 8, 9, 11 and for Introjected Regulation: 2, 3, 5, 7, 10, 12. The construct of 12 items were back-translated by two language experts from the Faculty of Major Language Studies, USIM to ensure that the items do not lose its original meaning.

\section{RESULTS AND DISCUSSION}

The research process can be divided into three sections: (a) back translation process, (b) validity, and (c) reliability. 


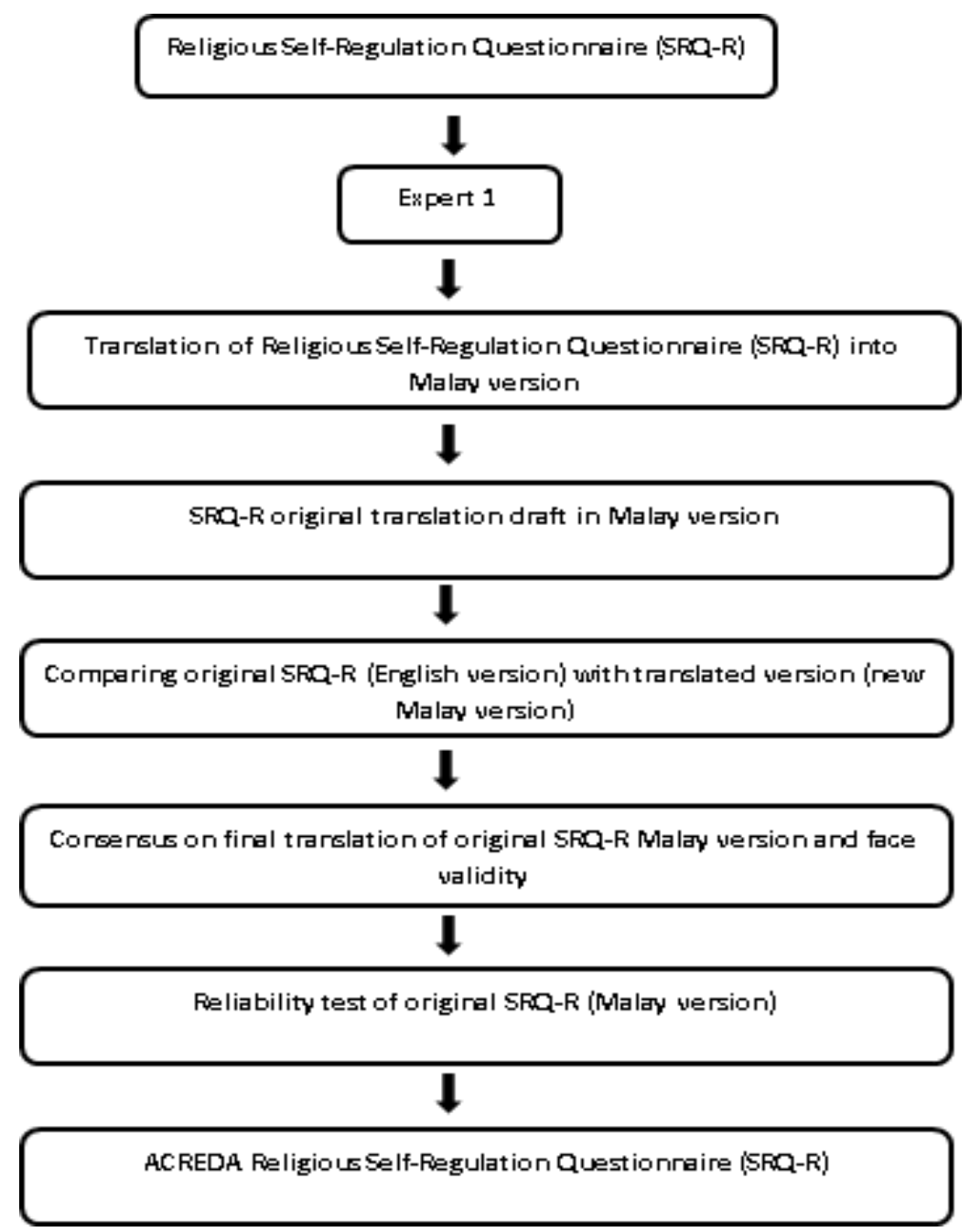

\section{Diagram 1: Procedures of Malay Version for ACREDA Self-Regulation Questionnaire (ASRQ-R)}

Back translation: This is an important process as to ensure the respondent vividly understand items in the instrument. Besides, back translation is done to help respondents easily understand the instrument in their native language as Malay is the main language used by most Muslims in Malaysia.

The process of translating was conducted by two language experts at the Faculty of Major Languages, USIM. The first language expert was responsible for translating the instrument into a different language while maintaining the meaning of the original items.

After that, the instrument was back-translated by another language expert to make sure that the meaning is still intact. Based on the back translation process, the authors were satisfied with translation provided by the two language experts. As mentioned by Douglas \& Craig (2007), the function of back translation were to detect errors in translations as well as the extensive 
checking, translation pre-testing and debriefing, in order to ensure the translation will be reliable and accurate. This is the reason why back translation is labelled as quality-control check, due to the few stages of process done in the beginning.

Validity: Validity is a process for a construct-based research measure what it should measure. Validity is an ability of a tool to measure what it is required to measure in which the researcher will test, compare and measure for the instruments' content, construct and face validity (Kumar \& Govindarajo, 2014). In this study, two senior lecturers from the Counseling program at the Faculty of Leadership and Management, USIM were approached to provide face validity for the instrument. They were given the Malay version of the instrument and were asked on the content of the items. This is supported by Jasmi, Zakaria and Norwaliza (2015) who stated that face validity should only be done by experts in the field. In this case, the two counselors act as experts as they are licensed counselors who have experience in doing modules.

Face validity is acceptable method of looking at the item of the instrument and how respondents understand it. Thus, face validity functions as a helping method in measuring items in the instrument as they appear to the respondents. Face validity has been considered as one of the simplest well-known methods of assessing validity for an instrument because it does not involve any statistical analysis while still being accepted as a valid measure (Brickman, Rabinowits, Karuza, Coates, Cohn \& Kidder, 1982).

Table 2.0: Reliability Statistics

\begin{tabular}{|l|l|l|}
\hline Cronbach's Alpha & $\begin{array}{l}\text { Cronbach's Alpha Based } \\
\text { on Standardized Items }\end{array}$ & N of Items \\
\hline .889 & .895 & 12 \\
\hline
\end{tabular}

Reliability: Reliability is a tool used to look at the consistency of the instrument to measure the construct. Yusliza \& Ramayah (2012) stated that reliability can be tested through the use of internal consistency evaluation. This will produce an Alpha Cronbach value. In order to reach the standard of reliability, value of Alpha Cronbach must be at least

0.6 and above. In this research, the translated version of ACREDA Religious Self-Regulation Questionnaire into Malay has an alpha value of 0.895 . This indicates a high reliability value for the instrument. This result show that the translated instrument is can be used as a measurement tool in Malaysia especially in a drug rehabilitation center especially for the Malay Muslim population.

Table 3.0: Case processing summary

\begin{tabular}{|l|l|l|}
\hline & N & $\%$ \\
\hline Cases $\quad$ Valid & 86 & 100.0
\end{tabular}


INTERNATIONAL JOURNAL OF ACADEMIC RESEARCH IN BUSINESS AND SOCIAL SCIENCES

Vol. 8, No. 11, Nov, 2018, E-ISSN: 2222-6990 @ 2018 HRMARS

\begin{tabular}{|l|l|l|} 
Excluded $^{\mathrm{a}}$ & 0 & .0 \\
Total & 86 & 100.0 \\
\hline
\end{tabular}

a. Listwise deletion based on all variables in the procedure.

Table 3.0 indicate the number of participants selected from Cure and Care Vocational Centre Sepang as respondents in the study. All of the respondents are Malay Muslims and male with ranging age of 21 to 50 . The demographic was chosen as stated in order to easier the questionnaire been spread in one belief which it is one of the target in this study.

Table 4.0: Summary Item Statistics

\begin{tabular}{|l|l|l|l|l|l|l|l|}
\hline & Mean & Minimum & Maximum & Range & $\begin{array}{l}\text { Maximum } \\
\text { Minimum }\end{array}$ & Variance & $\begin{array}{l}\text { Items } \\
\text { Itef }\end{array}$ \\
\hline $\begin{array}{l}\text { Item } \\
\text { Means }\end{array}$ & 6.578 & 6.337 & 6.756 & .419 & 1.066 & .020 & 12 \\
\hline
\end{tabular}

Table 4.0 indicated the summary item statistics of the instrument, with a mean 6.578 , range of 0.419 and variance of 0.020 among all of the 12 items used. The table show a descriptive statistics functioning as basic measures that include the mean, range and variance. The value stated is an average score on a variable to measure how different scores are from one another.

\section{CONCLUSION}

The Alpha Cronbach score indicate that the instrument is highly reliable and is safe to use in a Malaysian context. The ASRQ- $R$ is therefore a valid and reliable instrument. There are two major findings from the study. First, this study is important as the first step in using validated questionnaires to measure an individual's religious behavior, especially among drug addicts. Religion is an important component for most Malaysians, so the use of an instrument that could correctly measure their religious behavior is vital. Second, this study has found that this instrument could be used for the Malay Muslim population in Malaysia. This is important as most drug addicts in Malaysia are Malay Muslims, so a lot of studies are usually conducted on the population. So, other studies could also use this instrument if it focuses more on the same population. However, as this is just an initial study, more research still needs to be done to support the findings of this study as it's use for a more ethnically diverse, non-Malay Muslim population has yet to be conducted. It is recommended that reliability and validity study of the ASRQ-R be conducted on other ethnicities in Malaysian (e.g.: Chinese, Indian, Sabah and Sarawak natives) so that it could be used for all Malaysians. 
INTERNATIONAL JOURNAL OF ACADEMIC RESEARCH IN BUSINESS AND SOCIAL SCIENCES

Vol. 8, No. 11, Nov, 2018, E-ISSN: 2222-6990 (C) 2018 HRMARS

\section{REFERENCES}

Allahverdipour, H., H. Maclntyre, R., Hidarnia, A., Shafii, F., Kazemnegad, A. (2007). Assessing protective factors against drug abuse among high school students: Self-control and the extended parallel process model. Journal of Addiction Nursing, 18, 65-73.

Amey, C. H., Albrecht, S. L., Miller, M. K. (1996). Racial differences in adolescent drug use: The impact of religion. Substance Use and Misuse, 31, 1311-1332.

Amoateng A. Y., \& Bahr, S. J. (1986). Religion, family, and adolescent drug use. Sociological Perspectives, 29(1), 53-76.

Bahr, S. J., Maughan, S. L., \& Marcos, A. C., \& Li, B. (1998). Family, religiosity, and the risk of adolescent drug use. Journal of Marriage and the Family, 60, 979-992.

Brambilla, M., Manzi, C., \& Camillo, R. (2014) Italian Validation of the Christian Religious Internalization Scale. Catholic University of Milano, 21(2).

Brickman, P., Rabinowits, C. V., Karuza, J. J., Coates, D., Cohn, E., \& Kidder, L. (1982). Models of helping and coping. American Psychologist, 37, 368-384.

Douglas, S. P., \& Craig, C. S. (2007). Collaborative and iterative translation: An alternative approach to back translation. Journal of International Marketing, 15, 30-43.

Halpert, R. and R. Hill (2011). 28 measures of locus of control. New Jersey, NJ: Will To Power Press.

Hill, P. C. \& Hood, R. W. Jr. (Eds.) (1999). Measures of religiosity (pp. 124-127). Birmingham, AL: Religious Education Press.

Jasmi, A.T, Zakaria, M. \& Norwaliza, A. W. (2015). Validity and reliability of career exploration module. Middle-East Journal of Scientific Research, 23(11), 2639-2644.

Kumar, M.D. \& Govindarajo, N. S. (2014). Instrument development: Intention to leave instrument. Middle- East Journal of Scientific Research, 21(3), 509-517.

Kutter, C. J. \& McDermott, D. S. (1997). The role of the church in adolescent drug education. Journal of Drug Education, 27, 293-305.

National Anti- Drug Agency (NADA), 2015. Drug Report 2015. Bangi, Malaysia: Ministry of Home Affairs Malaysia. 
INTERNATIONAL JOURNAL OF ACADEMIC RESEARCH IN BUSINESS AND SOCIAL SCIENCES

Vol. 8, No. 11, Nov, 2018, E-ISSN: 2222-6990 @ 2018 HRMARS

Ryan, R. M., Rigby, S. \& King, K. (1993). Two types of religious internalization and their relations to religious orientations and mental health. Journal of Personality and Social Psychology, 65, 586-598. 